\title{
Usability of citizen science observations together with airborne laser scanning data in determining the habitat preferences of forest birds
}

\author{
Mononen, Laura
}

\section{8-12-15}

Mononen , L , Auvinen , A-P , Packalen , P , Virkkala , R, Valbuena , R, Bohlin , I , Valkama , J \& Vihervaara , P 2018 , ' Usability of citizen science observations together with airborne laser scanning data in determining the habitat preferences of forest birds ' , Forest Ecology and Management, vol. 430 , pp. 498-508 . https://doi.org/10.1016/j.foreco.2018.08.040

http://hdl.handle.net/10138/326396

https://doi.org/10.1016/j.foreco.2018.08.040

cc_by_nc_nd

acceptedVersion

Downloaded from Helda, University of Helsinki institutional repository.

This is an electronic reprint of the original article.

This reprint may differ from the original in pagination and typographic detail.

Please cite the original version. 

scanning data in determining the habitat preferences of forest birds

Keywords: Citizen Science (CS), Airborne laser scanning (ALS), Light detection and ranging (LiDAR),

Mononen, L. ${ }^{a b}{ }^{*}$, Auvinen, A.-P. ${ }^{a}$, Packalen, P. ${ }^{c}$, Virkkala, R. ${ }^{a}$, Valbuena, R. ${ }^{d}$, Bohlin, I. ${ }^{e}$, Valkama, J. ${ }^{f}$ Vihervaara, $P .^{a}$

a) Finnish Environment Institute (SYKE), Joensuu, Oulu, and Helsinki Offices, P.O. Box 140, 00251 Helsinki, Finland.

b) Department of Geographical and Historical Studies, University of Eastern Finland (UEF), P.O. Box 111, 80101 Joensuu, Finland

c) School of Forest Sciences, University of Eastern Finland (UEF), P.O. Box 111, 80101 Joensuu, Finland.

d) University of Cambridge, Department of Plant Sciences, Forest Ecology and Conservation, Downing Street, Cambridge CB2 3EA, United Kingdom.

e) Swedish University of Agricultural Sciences (SLU), Department of Forest Resource Management, SE-901 83, Umeå, Sweden.

f) Finnish Museum of Natural History (Luomus), P.O. Box 17, FI-00014 University of Helsinki, Finland.

\section{SUMMARY}

1. Citizens' field observations are increasingly stored in accessible databases, which makes it possible to use them in research. Citizen science (CS) complements the field work that must necessarily be carried out to gain an understanding of any of bird species' ecology. However, CS data holds multiple biases (e.g. presence only data, location error of bird observations, spatial data coverage) that should be paid attention before using the data in scientific research.

2. The use of Airborne Laser Scanning (ALS) enables investigating forest bird species' habitat preferences in detail and over large areas. In this study the breeding time habitat preferences of 25 forest bird species were investigated by coupling CS observations together with nine forest structure parameters that were computed using ALS data and field plot measurements. Habitat preferences were derived by comparing surroundings of presence-only observations against the full landscape. Also, in order to account for bird observation location errors, we analysed several buffering alternatives.

3. The results correspond well with the known ecology of the selected forest bird species. The size of a bird species' territory as well as some behavioural traits affecting detectability (song volume, mobility etc.) seemed to determine which bird species' CS data could be analysed with this approach. Especially the habitats of specialised species with small or medium sized territories differed from the whole forest landscape in the light of several forest structure parameters. Further research is needed to tackle issues related to the behaviour of the observers (e.g. birdwatchers' preference for roads) and characteristics of the observed species (e.g. preference for edge habitats), which may be the reasons for few unexpected results.

4. Our study shows that coupling CS data with ALS yield meaningful results that can be presented with distribution figures easy to understand and, more importantly, that can cover areas larger than what is normally possible by means of purpose-designed research projects. However, the use of CS data requires an understanding of the process of data collection by volunteers. Some of the biases in the data call for further thinking in terms of how the data is collected and analysed. 
Citizen science (CS) involves the collaboration of professionals and non-professionals in scientific research. During the past decades citizen participation has become a common practice in collecting ecological data for environmental monitoring (Conrad \& Hilchey 2011; Dickinson et al. 2012). Due to their detectability and the high level of ornithological expertise among non-professionals, birds are among the species groups of which CS observations hold the most potential to be used in research. There are several well-established procedures for sampling birds that contain elements of CS (e.g. Sullivan et al. 2009; Laaksonen \& Lehikoinen 2013). Observation schemes involving a strong CS component have been used to study the timing of migration (Jonzén et al. 2006; Saino et al. 2010; Lehikoinen et al. 2013). However, few if any previous attempts have been made to use CS data in studying the habitat preferences of forest birds, especially in connection with remote sensing.

Information on habitat characteristics has improved both in terms of accuracy and spatial extent over the past century along with the development of remote sensing (RS) techniques (Kerr \& Ostrovsky 2003; Cohen \& Goward 2004). In particular, habitat and species distribution modelling have benefited a great deal from the development of RS, which supplements or sometimes even replaces traditional field work (Pettorelli et al. 2014). Airborne Laser Scanning (ALS) provides three-dimensional information which greatly advances the spatial analysis of habitat structures (e.g. Lefsky et al. 2002; Hill \& Thompson 2005; Davies \& Asner 2014; Valbuena et al. 2017) and helps detecting changing patterns of habitat use in a changing climate (Melin et al. 2014). Since human activity has a strong effect on the structural complexity of forests (e.g. Brokaw \& Lent 1999), ALS derived information has been acknowledged valuable for biodiversity assessments (Vierling et al. 2008). ALS parameters assist in the detection of those species that depend on or benefit from the structural heterogeneity of canopy structure (Goetz et al. 2007; Vierling et al. 2008; Palminteri et al. 2012).

Birds are a species group that respond to environmental changes relatively promptly (Barbet-Massin et al. 2012; Frishkoff et al. 2014; Virkkala \& Lehikoinen 2014) which makes them, along with several other characteristics (including ecological traits such as position in a food chain and non-ecological traits such as popularity), good indicators of biodiversity (Butchart et al. 2010; Gregory \& van Strien 2010). Traditionally, forest bird-habitat relations have been studied in the field by measuring certain habitat variables (e.g. tree species, height, diameter etc.) and connecting these measurements with bird observations (see e.g. MacArthur \& MacArthur 1961, Wiens 1989a and references therein). This kind of analysis produces detailed information of species' habitat selection, but can usually be carried out only over relatively small areas. Importantly, there is also stochasticity in species occurrence, which makes difficult to extrapolate results of bird-habitat studies conducted at fine scales (Wiens et al. 1987; Haila et al. 1996; Virkkala \& Rajasärkkä 2006). Bird-habitat relationships must therefore be studied on different spatial scales (Wiens et al. 1987; Wiens 1989b). On the other hand, ALS and other RS datasets connected with species observations can be used over large areas, and thus they are not susceptible to 
small scale variation in the occurrence of bird species. In fact, the Group on Earth Observations Biodiversity Observation Network (GEO BON) has identified the potential of remote sensing and in situ data combinations to contribute for extensive and cost-efficient biodiversity monitoring (GEOBON 2015). Using high quality CS observation could greatly advance this goal.

Several previous studies have proven the capability of ALS derived parameters to predict the speciesrichness of habitats (reviewed in Simonson et al. 2014) and, more recently, the differentiation of diversity among habitats (e.g. Zellweger et al. 2017). Further, some studies have successfully examined the specific species-habitat relations by using ALS, but these have focused only on a few habitat indicators or species or both (e.g. Graf et al. 2009; Goetz et al. 2010; Hagar et al. 2014; Melin et al. 2016). To date, 106 only few papers have examined the habitat preferences of multiple forest song birds with ALS. E.g. in Hinsley et al. (2009) and Müller et al. (2009) the observation data was surveyed by professional ecologists. To our knowledge, no previous studies have examined the use of CS data as rigorously (but

In this study we explore the extent to which CS data can be used to assess the habitat preferences of forest birds, and identify potential pitfalls when doing so. We use positioned observations from 25 forest bird species and nine ALS derived parameters to: I) Explore whether CS observations in connection with ALS based forest structure parameters can provide information that is in line with the known ecological characteristics (e.g. habitat preferences) of the bird species included in the study, II) Investigate which

\section{MATERIALS AND METHODS}

\subsection{Study area}

Examine which forest structure parameters are most suitable for predicting bird species' habitats in this connection. In order to facilitate the replicability of the method, the low-density ALS data were used as today they are typically acquired at national scale. However, we used a selection of ALS derived forest parameter layers that can be computed with field plot measurements to examine whether they can offer more detailed or complementary information for research. The potential applications of our study relate not only to the field of animal ecology, but can also help in determining where to focus conservation activities (Rose et al. 2015). Potentially, the combination of CS observations and ALS data could enable us to cover areas as large as administrative regions or even nations, and, in the future, also to model and predict the occurrence of species of conservation interest. 
The study area is located in Southern Finland in the Lake Vanajavesi catchment area of $3000 \mathrm{~km}^{2}$ (Figure 1). The area belongs to the southern boreal taiga vegetation zone and the landscape is dominated by boreal forests. The majority of the forests are commercially managed. Large lakes and small rivers, agricultural areas and wetlands are also typical in the area. The study area was selected based on the available ALS data and CS bird observations.

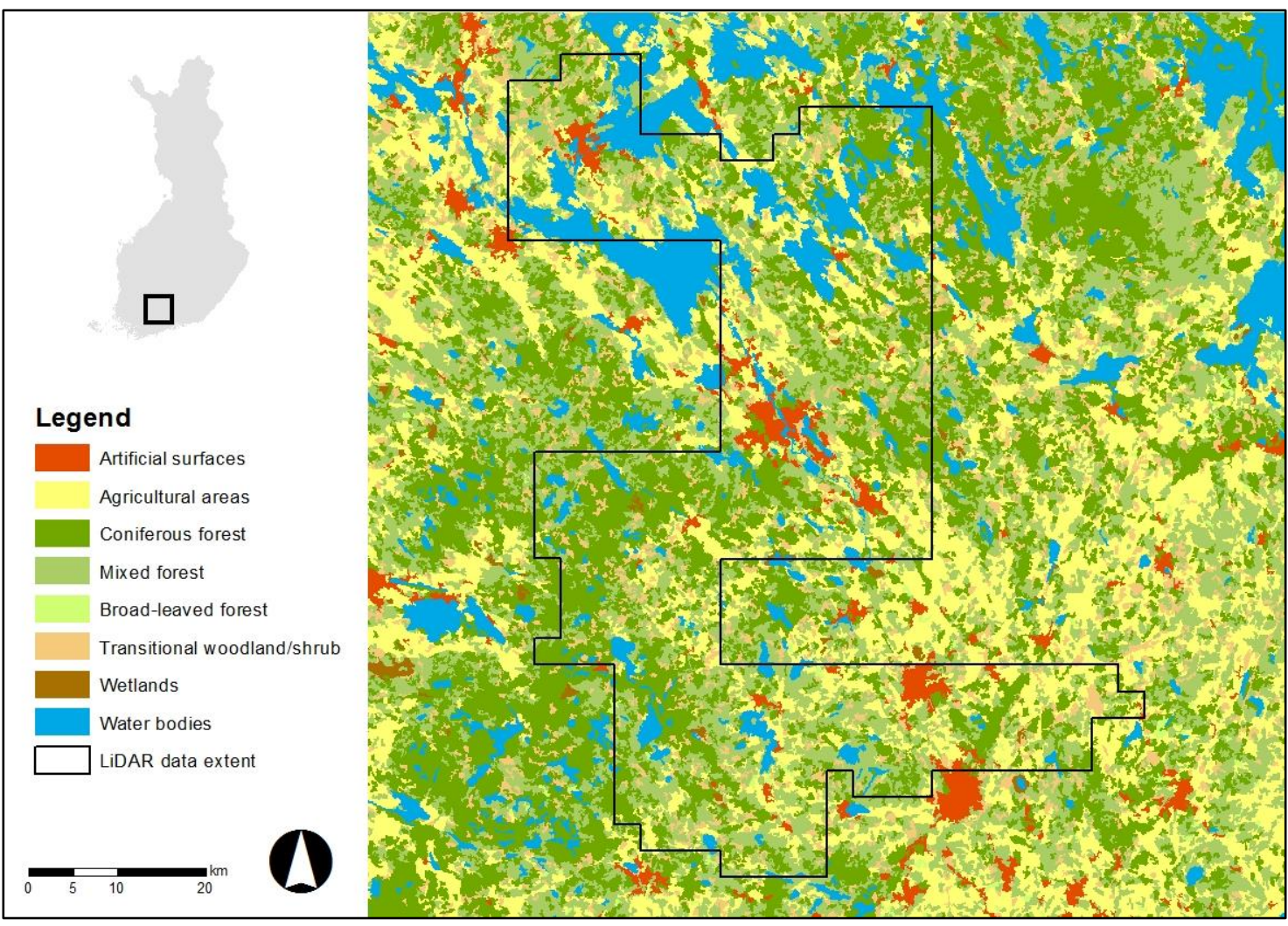

Figure 1. The study area is located in southern Finland. The area is determined by the coverage of ALS data (black line). Data: Corine Land Cover 2012.

\subsection{Species observations}

In our study, we included species of conservation concern, such as the European Union's Birds Directive Species (Annex I) and redlisted species in Finland, species preferring old-growth or mature forests, and species of herb-rich, lush, and deciduous forests (see Vihervaara et al. 2015). We also included species occurring in boreal agricultural-forest mosaics. The forest bird observation data were acquired from two sources; (i) Bird Atlas data from the database of the Finnish Museum of Natural History and (ii) faunistic observations from the Tiira database maintained by BirdLife Finland. Both of these data have been collected by mostly non-professional volunteers and, although the Bird Atlas was more goal-oriented and structured, can be described with good reason as citizen science. All observations were recorded in years 2006-2012. Only the observations that had higher location accuracy than $100 \mathrm{~m}$ (marked by the observers) were included in the final dataset. For each species only the observations during their known breeding time were included in the data. In the end, 25 bird species were included and the numbers of observations per species vary between 31 and 355 (Table 1). 
Table 1. Bird occurrence data points ( $\mathrm{N}$ of points), separated by data source (Atlas and Tiira), each species territory size and observation distance.

\begin{tabular}{|c|c|c|c|c|c|c|c|c|}
\hline & $\begin{array}{l}\text { Abbrevia } \\
\text { tion }\end{array}$ & Latin name & English name & $\begin{array}{l}\text { N of } \\
\text { point } \\
S\end{array}$ & $\begin{array}{l}\text { Tiira } \\
\text { data }\end{array}$ & $\begin{array}{l}\text { Atlas } \\
\text { data }\end{array}$ & $\begin{array}{l}\text { Home } \\
\text { range } \\
\text { size* }\end{array}$ & $\begin{array}{l}\text { Observat } \\
\text { ion } \\
\text { distance } \\
* *\end{array}$ \\
\hline 1 & ACCGEN & Accipiter gentilis & Goshawk & 90 & 70 & 20 & $\mathrm{~L}$ & 396 \\
\hline 2 & ACCNIS & Accipiter nisus & Sparrowhawk & 81 & 73 & 8 & $\mathrm{~L}$ & 171 \\
\hline 3 & AEGCAU & Aegithalos caudatus & Long-tailed Tit & 121 & 111 & 10 & $\mathrm{~S}$ & 20 \\
\hline 4 & AEGFUN & Aegolius funereus & Boreal Owl & 54 & 48 & 6 & $\mathrm{~L}$ & 483 \\
\hline 5 & ASIOTU & Asio otus & Long-eared Owl & 148 & 128 & 20 & $\mathrm{~L}$ & 266 \\
\hline 6 & BONBON & Bonasa bonasia & Hazel Grouse & 315 & 303 & 12 & $M$ & 21 \\
\hline 7 & BUBBUB & Bubo bubo & Eagle Owl & 31 & 25 & 6 & $\mathrm{~L}$ & 487 \\
\hline 8 & BUTBUT & Buteo buteo & Buzzard & 57 & 47 & 10 & $\mathrm{~L}$ & 167 \\
\hline 9 & CAPEUR & Caprimulgus europaeus & Nightjar & 39 & 35 & 4 & $M$ & 234 \\
\hline 10 & DENMIN & Dendrocopos minor & Lesser Spotted Woodpecker & 232 & 221 & 11 & $\mathrm{M}$ & 62 \\
\hline 11 & DRYMAR & Dryocopus martius & Black Woodpecker & 330 & 319 & 11 & $\mathrm{~L}$ & 169 \\
\hline 12 & FICPAR & Ficedula parva & Red-breasted Flycatcher & 42 & 33 & 9 & $\mathrm{~S}$ & 50 \\
\hline 13 & GLAPAS & Glaucidium passerinum & Pygmy Owl & 57 & 51 & 6 & $\mathrm{~L}$ & 166 \\
\hline 14 & HIPICT & Hippolais icterina & Icterine Warbler & 119 & 109 & 10 & $S$ & 60 \\
\hline 15 & JYNTOR & Jynx torquilla & Wryneck & 92 & 82 & 10 & $\mathrm{~S}$ & 77 \\
\hline 16 & LUSLUS & Luscinia luscinia & Thrush Nightingale & 355 & 342 & 13 & $\mathrm{~S}$ & 254 \\
\hline 17 & PERAPI & Pernis apivorus & Honey Buzzard & 77 & 69 & 8 & $\mathrm{~L}$ & 165 \\
\hline 18 & PHYDES & Phylloscopus trochiloides & Greenish Warbler & 34 & 29 & 5 & $S$ & 40 \\
\hline 19 & PICCAN & Picus canus & Grey-headed Woodpecker & 216 & 203 & 13 & $\mathrm{M}$ & 120 \\
\hline 20 & PICTRI & Picoides tridactylus & Three-toed Woodpecker & 44 & 36 & 8 & $\mathrm{M}$ & 28 \\
\hline 21 & STRALU & Strix aluco & Tawny Owl & 150 & 126 & 24 & $\mathrm{~L}$ & 382 \\
\hline 22 & STRURA & Strix uralensis & Ural Owl & 78 & 71 & 7 & $\mathrm{~L}$ & 450 \\
\hline 23 & TETRIX & Tetrao tetrix & Black Grouse & 155 & 151 & 4 & $L$ & 302 \\
\hline 24 & TETURO & Tetrao urogallus & Capercaillie & 133 & 127 & 6 & $L$ & 35 \\
\hline 25 & TURVIS & Turdus viscivorus & Mistle Thrush & 42 & 35 & 7 & $M$ & 58 \\
\hline
\end{tabular}

* The size of the area over which the species is likely to be observed during the breeding period (normally the territory that the birds defend by singing, but in some cases a larger area used for hunting etc.); $L=$ large, $>100$ ha; $\mathrm{M}=$ medium, 10-100 ha; $\mathrm{S}=$ small, $<10$ ha. 


\subsection{ALS data}

169

170

171

172

173

174

175

176

177

178

179

180

181

182

183

184

185

186

187

188

189

190

191

192

193

194

195

196

197

198

199

200

201

202

203

204

205

ALS data were collected on May-June 2008 using Optech ALTM GEMINI laser scanning system. The ALS data point is offset at most by four years from the bird data (2006-2012). In a previous study a gap of this size between the acquisition of ALS and CS data was found to be of marginal impact on the results (Vierling et al. 2014). The area was measured from an altitude of 2000 metres above ground level using half angle of $20^{\circ}$. This resulted in a swath width of 1450 metres and a nominal sampling density of about 0.5 measurements per square metre. A digital terrain model (DTM) was generated from the ALS data by classifying ALS echoes as ground points and other points as explained in Axelsson (2000). Finally, the orthometric heights of ALS echoes (Z) were converted to above ground heights (dZ) by subtracting the DTM at the corresponding location.

\subsection{Forest sample plots}

The sample plot data were acquired during the summers of 2007 and 2008. A network of circular sample plots with a radius of 9 meters was established on the area. Sample plots were placed over forest stands with different development stages and dominant tree species. Only one sample plot was placed to a stand so usually the distance between nearest plots is at least hundreds of meters. A total of 249 sample plots were measured. The Global Positioning System with differential correction was used to determine the position of the centre of each plot to an accuracy of about 1 meter (the accuracy of the positioning system was tested in a comparable forest area; unpublished data). The diameter at breast height (DBH) and tree species were recorded for all trees with $\mathrm{DBH}$ above $5 \mathrm{~cm}$. Tree height was measured from basal area median tree by tree species and storey class on each plot. Näslund's (1937) model was used to predict the height for the rest of the trees. The size of each individual tree was described by its basal area, stem volume and the biomass stocked above ground. Stem volume was predicted using models by Laasasenaho (1982) and above ground biomass ( $A G B$ ) using models by Repola et al. (2007). Plot level stem volumes and AGBs were computed by summing up individual trees by plot and finally species proportions (Pine, Spruce and Deciduous) were calculated based on plot volume. Dominant height (Hdom) was determined at the plot level as the mean height of the 100 trees with the largest diameter at breast height per hectare. Forest structure was described by two parameters: the Gini coefficient (GC) and the proportion of basal area larger than mean (BALM), respectively describing tree size dispersion and asymmetry (Valbuena et al. 2013). The GC measures the relative inequality in individual tree basal areas, and therefore it evaluates the heterogeneity of tree sizes in the forest population (Weiner \& Solbrig 1984). Using GC to describe forest structural heterogeneity is similar to the more common parameter for foliage height diversity $(F H D)$ based on Shannon's diversity (MacArthur \& MacArthur 1961), which is more commonly used in ALS-based studies (e.g. Clawges et al. 2008). Valbuena et al. (2012) explained the mathematical links between these two parameters and why GC was preferred above $F H D$. On the other hand, BALM was used to evaluate relative dominance among various tree 
storeys, since understorey ingrowth decreases the proportion of basal area stocked above its mean, and hence BALM (Gove 2004; Valbuena et al. 2015).

\subsection{Forest structure parameters}

We considered two main types of ALS derived forest structure parameters (Table 2): (i) those estimated using the field sample plot data together with metrics computed from the ALS data (Næsset 2002; Maltamo et al. 2005; Valbuena et al. 2013; Asner \& Mascaro 2014) and (ii) those calculated directly from the ALS data (Nelson et al. 1984; Miura \& Jones 2010; Valbuena et al. 2017). The variables of former group were first modelled using field sample plots as response variables and ALS metrics as predictor variables (Vihervaara et al. 2015). This group consists of parameters: AGB, Hdom, GC, BALM, Pine, Spruce and Deciduous. Error rates and biases were reported in Vihervaara et al. (2015). The latter group were metrics calculated directly from the heights above ground of ALS echoes (dZ), which have been demonstrated to be directly related to the structural properties of forests. One such metric was the proportion of ALS echoes backscattered from of vegetation ( $F_{-} v e g$ ), in other words, those echoes that are backscattered from vegetation above half a meter. $F_{-}$veg is regarded as a good proxy for canopy cover (Nelson et al. 1984). Another metric employed was the coefficient of L-skewness (Lskew) (Hosking 1990), which has been regarded as a good proxy for light availability and therefore understorey regeneration (Valbuena et al. 2017). Finally, forest parameters were either predicted or calculated to the whole study area using a grid with $15 \mathrm{~m}$ cell size.

Table 2. Forest structure parameters that were used in this study.

\begin{tabular}{|c|c|c|c|}
\hline Code & Description & Resolution & Data used \\
\hline$A G B$ & Above ground biomass of trees $(\mathrm{Mg} / \mathrm{ha})$ & $15 \mathrm{~m}$ & ALS + sample plots \\
\hline$B A L M$ & $\begin{array}{l}\text { Basal area larger than mean: Relative } \\
\text { development of overstorey and } \\
\text { understorey (Valbuena et al. 2013). }\end{array}$ & $15 \mathrm{~m}$ & ALS + sample plots \\
\hline $\begin{array}{l}\text { Deciduous } \\
\text { (\%) }\end{array}$ & $\begin{array}{l}\text { Proportion of deciduous trees (\%) with } \\
\text { respect to stem volume }\end{array}$ & $15 \mathrm{~m}$ & ALS + sample plots \\
\hline$F_{-} v_{e g}^{*}$ & $\begin{array}{l}\text { Proportion of vegetation ALS echoes (\%). } \\
\text { An ALS proxy for amount of canopy } \\
\text { cover (Nelson et al. 1984). }\end{array}$ & $15 \mathrm{~m}$ & ALS only \\
\hline$G C^{*}$ & $\begin{array}{l}\text { Gini coefficient. Inequality of sizes among } \\
\text { trees (Valbuena et al. 2012). }\end{array}$ & $15 \mathrm{~m}$ & ALS + sample plots \\
\hline $\operatorname{Hdom}(m)^{*}$ & $\begin{array}{l}\text { Dominant height of trees }(\mathrm{m}) \\
\text { Average upper canopy }\end{array}$ & $15 \mathrm{~m}$ & ALS + sample plots \\
\hline Lskew* & $\begin{array}{l}\text { L-Skewness of ALS echo heights. An } \\
\text { ALS proxy for light availability and } \\
\text { regeneration (Valbuena et al. 2017). }\end{array}$ & $16 \mathrm{~m}$ & ALS only \\
\hline Pine (\%) & $\begin{array}{l}\text { Proportion of pine (\%) with respect to } \\
\text { stem volume }\end{array}$ & $15 \mathrm{~m}$ & ALS + sample plots \\
\hline Spruce (\%) & $\begin{array}{l}\text { Proportion of spruce (\%) with respect to } \\
\text { stem volume }\end{array}$ & $15 \mathrm{~m}$ & ALS + sample plots \\
\hline
\end{tabular}

* These parameters could be computed from ALS data without field measurements. 


\subsection{Linking forest parameters to bird observations}

231 We generated buffers around bird observation points (Figure 2). To define a suitable buffer size that 232 captures relevant information on the surroundings of bird observation point, we generated buffers with $23330,50,100$ and $150 \mathrm{~m}$ radii. The forest parameter layers were intersected with the buffers assuming that 234 the cells having a centre point within the buffer are inside.

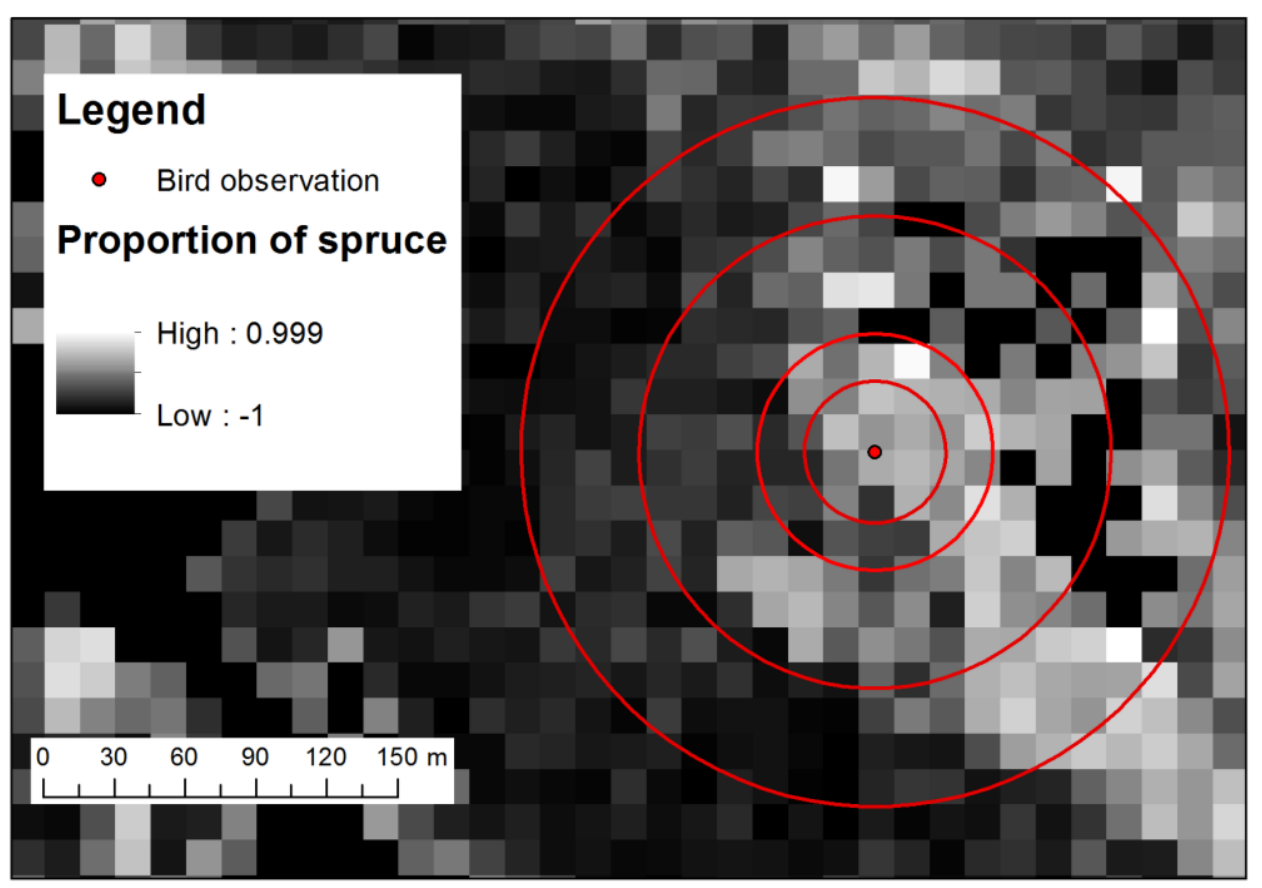

Figure 2. Buffers around observation points. As an example a forest parameters in the background (15 m grid).

The overlapping buffers were considered only once to avoid over-representation of areas where the same species had been observed many times. The cells that included urban or water areas were excluded from both datasets. For each buffer, data was processed for 25 birds and for 9 forest parameters $(25 \times 9=225)$. Additionally, a dataset that represents the landscape of the entire study area was created. Density curves were created for each bird and parameter combination and the landscape and they were normalized with respect to landscape. It was therefore employed as a measure of the divergence between the habitat preferences of a given species relative to what it is available in the whole study area.

We computed overlap (OL) and Kolmigorov-Smirnov's D (KS-D) metrics to all bird and forest parameter combinations and for the landscape. These were computed in the $\mathrm{R}$ environment using 'overlap'

253 (Meredith \& Ridout 2016) and 'stats' packages (R Core team 2016). The overlapping values indicate how 254 much the distribution of a certain forest parameter of a certain bird species sample and the landscape of 
the same forest parameter overlap (\%). Smaller percentages would indicate bigger differences between the distributions whereas an overlap value of 100 would mean perfect similarity.

258 We used Kolmogorov-Smirnov D statistics to measure the maximum distance between the empirical 259 distribution function of the sample and the cumulative distribution function of the landscape distribution. 260 Higher Kolmogorov-Smirnov D values indicate higher maximum difference between the two distributions 261 and therefore help detecting the species-specific habitat preferences "peaks" in relation to the chosen 262 forest parameters. The actual Kolmogorov-Smirnov significance test was not used because CS bird 263 observations cannot be considered as probability samples. Finally, profiles for each bird species with all 264 forest parameter were generated (see figure 4 as an example).

\section{RESULTS}

268 The Kolmogorov-Smirnov D statistics showed greater differences between the sample and landscape 269 when we used smaller buffers $(30 \mathrm{~m}$ and $50 \mathrm{~m}$ ). The results with two of the largest buffers (100 $\mathrm{m}$ and $270150 \mathrm{~m}$ ) appeared to lose information on bird-specific habitat preferences. An example of this effect is 271 shown in Fig. 3.). The D statistics captured the greatest differences with $30 \mathrm{~m}$ buffer. Across all species 272 and forest structure parameters, $50 \mathrm{~m}, 100 \mathrm{~m}$ and $150 \mathrm{~m}$ buffers respectively obtained differences $11 \%$, $27322 \%$ and $29 \%$ smaller than 30 m buffers. Therefore, the results in this paper are further reported only for $27430 \mathrm{~m}$ buffer for each bird species, because this buffer most accurately measures bird-habitat relations 275 (see Discussion).

276

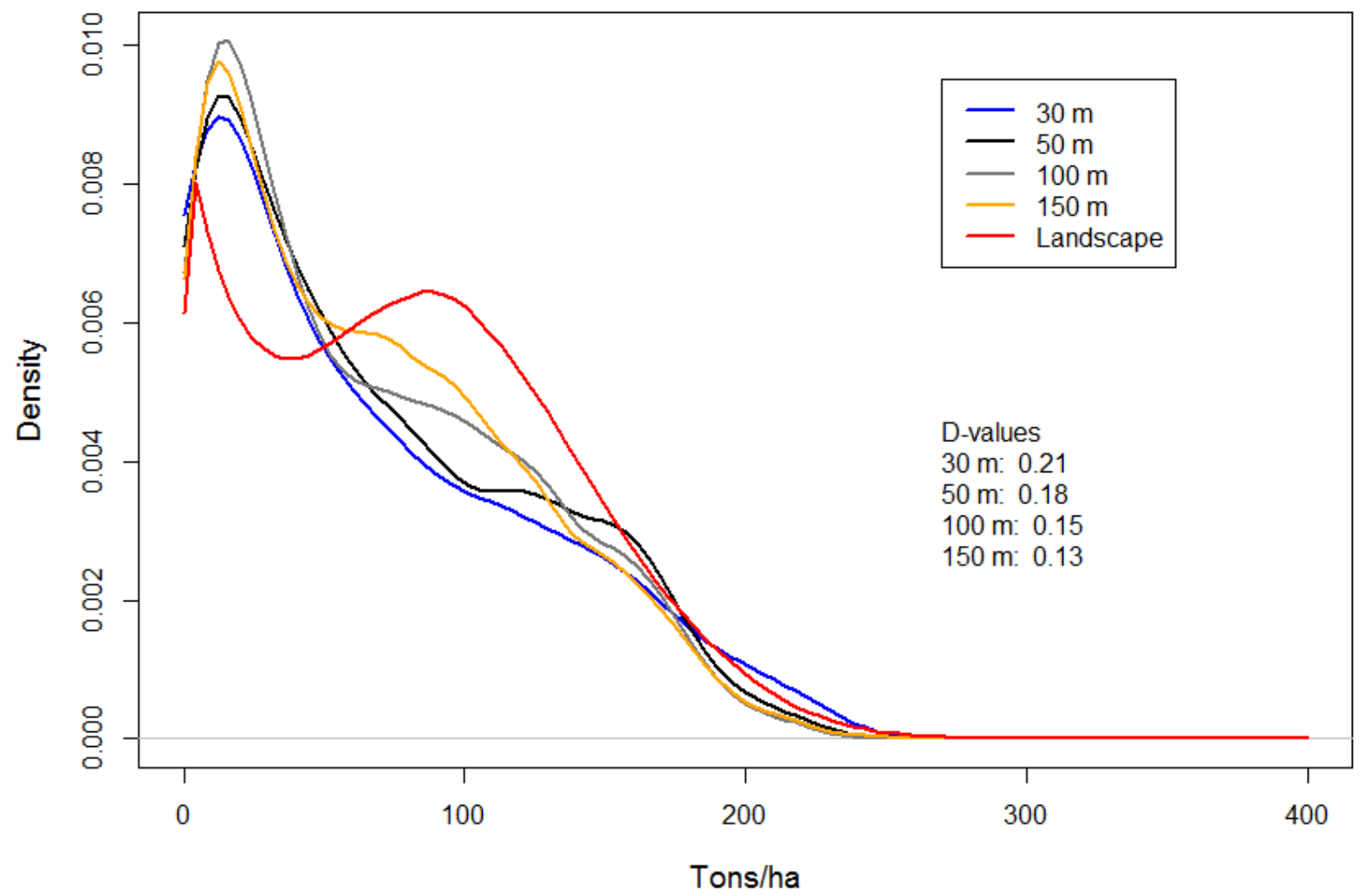


Figure 3. An example showing how the size of the buffer around each bird observation point affects the density curves and $D$ statistics as calculated for nightjar in relation to above ground biomass. The $D$ statistic expresses the maximum distance between the distribution curve representing the landscape (red line) and those of the nightjar observation points surrounded by different sized buffers).

\subsection{Landscape structure according to forest parameters}

The density curves computed at the landscape level are presented in red in figure 4 and ALS based forest parameters presented in Table 3. The landscape of the study area is highly covered by vegetation $\left(F_{-}\right.$veg). The largest part of the study area has quite a closed canopy structure (Lskew). Tree biomass is less than 100 ton/ha in the majority of the area $(A G B)$ and tree height is typically between 20-25 meters (Hdom). Spruce is the dominating tree species (Spruce \%), but pine trees are also common (Pine \%). The proportion of deciduous trees is low (Deciduous \%). The two three-dimensional parameters show that the largest part of the forests is even-sized $(G C)$, but also that the area includes structurally complex forests with a heterogeneous tree composition (BALM).

Table 3. Description of the landscape (excluding water and urban areas) in the light of the ALS based forest parameters (landscape curve in red in Figure 4). See Table 2 for parameters descriptions.

\begin{tabular}{ll}
\hline Parameter & How indicator defines study area? \\
\hline AGB & $\begin{array}{l}\text { Significant amount of areas where there is no tree biomass (fields, clear cuts). Forest } \\
\text { biomass is mostly below } 100 \text { ton/ha. }\end{array}$ \\
BALM & $\begin{array}{l}\text { Two peaks show that there are structurally complex forests with understorey } \\
\text { developed underneath the dominant canopies (lower peak), but that the greater } \\
\text { share of forests have a single-layered vertical structure of vegetation (higher peak). }\end{array}$ \\
Deciduous (\%) & $\begin{array}{l}\text { The proportion of deciduous trees is quite low. There are only a few purely deciduous } \\
\text { forest patches (> 80\%) pixels. }\end{array}$ \\
F_veg & $\begin{array}{l}\text { The proportion of vegetation hits shows that vegetation cover is high across the study } \\
\text { area. The high peak shows that vegetation is dense in a large share of the area. }\end{array}$ \\
GC & $\begin{array}{l}\text { Values below } 0.5 \text { indicate that the forests are mostly structurally homogenous. } \\
\text { Hdom (m) }\end{array}$ \\
Lskew & $\begin{array}{l}\text { Negative skewness indicates closed canopy structure and applies to majority of the } \\
\text { study area. }\end{array}$ \\
Pine (\%) & $\begin{array}{l}\text { There is rather high amount of forest with low percentage of pine. Pure pine forests } \\
\text { (< 80\%) are rare, but not as rare as pure deciduous forests. }\end{array}$ \\
Spruce (\%) & Spruce is the dominant tree species in the area. \\
\hline
\end{tabular}




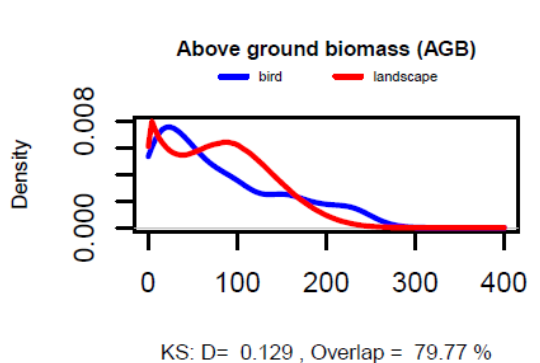

Proportion of vegetation hits (\%) (F_veg) - bird - landscape

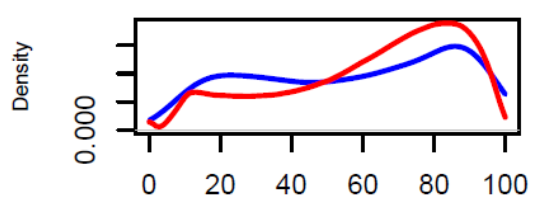

KS: $\mathrm{D}=0.12$, Overlap $=84.7 \%$

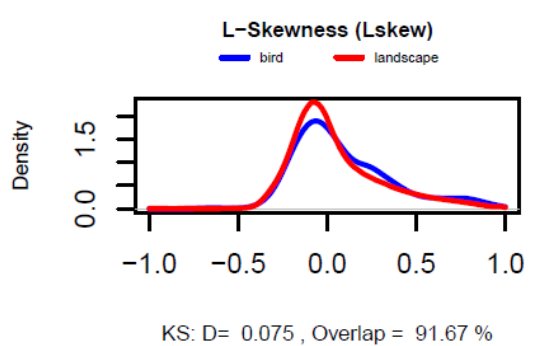

\section{Goshawk (ACCGEN)}

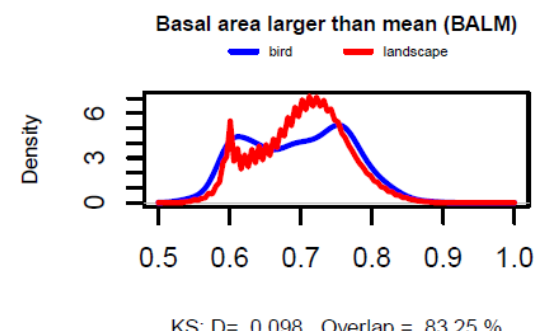

KS: $\mathrm{D}=0.098$, Overlap $=83.25 \%$

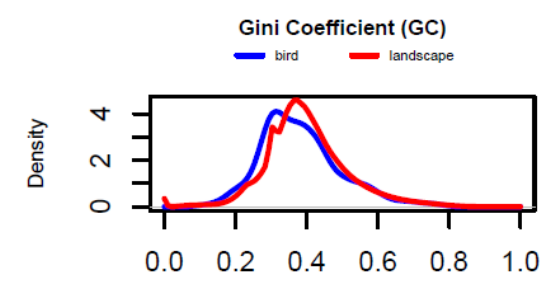

KS: $\mathrm{D}=0.115$, Overlap $=88.07 \%$

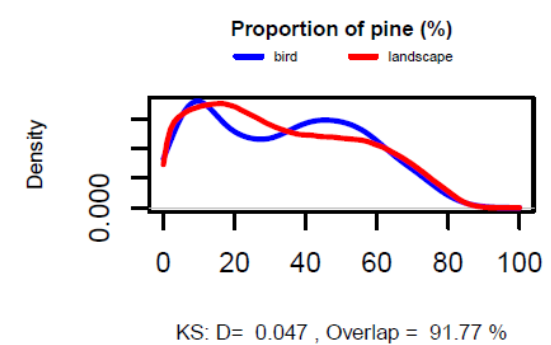

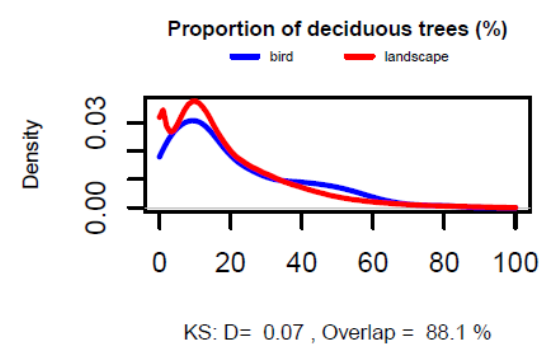

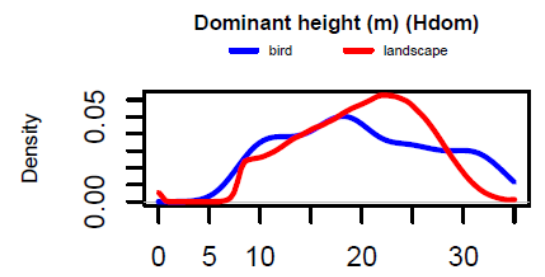

KS: $\mathrm{D}=0.121$, Overlap $=82.16 \%$

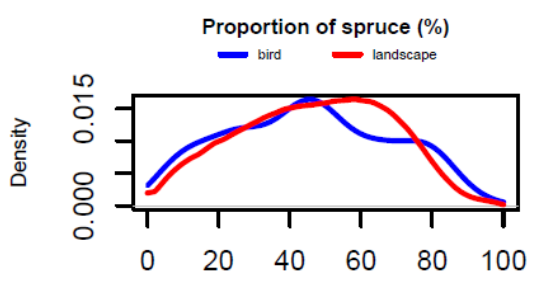

KS: $\mathrm{D}=0.063$, Overlap $=89.96 \%$

Figure 4. An example of a bird profile that was created for each species. In this case the 30 meter buffers around goshawk observation points (blue line) are compared with the landscape (red line).

\subsection{Bird species' habitat preferences}

Differences between the bird habitat preferences and the landscape characteristics were detected by calculating the D-values (Table 4) and overlapping metrics (Table 5). The results can be interpreted from several angles. One is to look over all the nine forest parameters and see which species' habitat use differ the most from the range of available habitat. The thrush nightingale's (LUSLUS) average D-value is clearly the highest (0.27) and its overlapping percentage lowest (72.3). The next two species ranked the same way are honey buzzard (PERAPI; 0.22 / 78.6\%) and three-toed woodpecker (PICTRI; 0.20 / 80.2\%). At the other end of the spectrum the two grouse species, western capercaillie (TETURO; 0.07 / 91.2\%) and hazel grouse (BONBON; $0.05 / 93.3 \%$ ), do not show much deviation from the available habitat at all. The $\mathrm{D}$-values and overlapping percentages rank the species mostly in the same order.

The species can also be ranked by looking at one forest parameter at a time. Four species, for example, receive a D-value of over 0.2 for dominant height. These are three-toed woodpecker (PICTRI; 0.34), redbreasted flycatcher (FICPAR; 0.29), thrush nightingale (LUSLUS; 0.23) and greenish warbler (PHYDES; 0.20 ). However, to understand how these species' habitat preference differs from the available habitat, 
Table 4. D-values for a $30 \mathrm{~m}$ buffer. Higher values indicate higher maximum difference between the distributions. Table cells in darker colours indicate greater differences between the habitat used by the bird species and that of the whole study area.

\begin{tabular}{|l|r|r|r|r|r|r|r|r|r|}
\hline Bird (30 m) & \multicolumn{1}{|c|}{ AGB } & BALM & Deciduous $\%$ & \multicolumn{1}{l}{ f_veg } & \multicolumn{1}{l|}{ GC } & Hdom & LSKEW & Pine $\%$ & Spruce $\%$ \\
\hline ACCGEN & 0,129 & 0,097 & 0,07 & 0,12 & 0,115 & 0,121 & 0,075 & 0,047 & 0,063 \\
\hline ACCNIS & 0,222 & 0,202 & 0,105 & 0,198 & 0,072 & 0,153 & 0,064 & 0,106 & 0,111 \\
\hline AEGCAU & 0,203 & 0,163 & 0,179 & 0,198 & 0,038 & 0,075 & 0,141 & 0,048 & 0,133 \\
\hline AEGFUN & 0,153 & 0,062 & 0,037 & 0,197 & 0,119 & 0,09 & 0,195 & 0,072 & 0,052 \\
\hline ASIOTU & 0,265 & 0,214 & 0,11 & 0,249 & 0,172 & 0,137 & 0,201 & 0,122 & 0,216 \\
\hline BONBON & 0,038 & 0,052 & 0,022 & 0,052 & 0,082 & 0,054 & 0,062 & 0,054 & 0,044 \\
\hline BUBBUB & 0,204 & 0,182 & 0,14 & 0,237 & 0,16 & 0,132 & 0,124 & 0,186 & 0,133 \\
\hline BUTBUT & 0,192 & 0,149 & 0,178 & 0,199 & 0,057 & 0,11 & 0,088 & 0,147 & 0,086 \\
\hline CAPEUR & 0,206 & 0,076 & 0,212 & 0,208 & 0,067 & 0,106 & 0,219 & 0,237 & 0,171 \\
\hline DENMIN & 0,156 & 0,091 & 0,313 & 0,137 & 0,097 & 0,061 & 0,089 & 0,084 & 0,231 \\
\hline DRYMAR & 0,146 & 0,086 & 0,11 & 0,169 & 0,066 & 0,041 & 0,138 & 0,041 & 0,081 \\
\hline FICPAR & 0,241 & 0,199 & 0,137 & 0,151 & 0,035 & 0,293 & 0,175 & 0,224 & 0,138 \\
\hline GLAPAS & 0,103 & 0,043 & 0,156 & 0,134 & 0,092 & 0,114 & 0,092 & 0,065 & 0,071 \\
\hline HIPICT & 0,17 & 0,129 & 0,184 & 0,19 & 0,114 & 0,033 & 0,084 & 0,084 & 0,234 \\
\hline JYNTOR & 0,264 & 0,223 & 0,107 & 0,258 & 0,117 & 0,119 & 0,124 & 0,064 & 0,13 \\
\hline LUSLUS & 0,367 & 0,322 & 0,167 & 0,336 & 0,285 & 0,232 & 0,206 & 0,179 & 0,354 \\
\hline PERAPI & 0,316 & 0,234 & 0,174 & 0,335 & 0,154 & 0,193 & 0,251 & 0,141 & 0,142 \\
\hline PHYDES & 0,053 & 0,068 & 0,095 & 0,069 & 0,059 & 0,201 & 0,066 & 0,155 & 0,061 \\
\hline PICCAN & 0,118 & 0,075 & 0,12 & 0,12 & 0,101 & 0,066 & 0,116 & 0,053 & 0,054 \\
\hline PICTRI & 0,292 & 0,287 & 0,186 & 0,128 & 0,078 & 0,339 & 0,174 & 0,224 & 0,13 \\
\hline STRALU & 0,153 & 0,084 & 0,15 & 0,179 & 0,069 & 0,058 & 0,124 & 0,063 & 0,103 \\
\hline STRURA & 0,188 & 0,088 & 0,124 & 0,222 & 0,081 & 0,057 & 0,148 & 0,05 & 0,086 \\
\hline TETRIX & 0,262 & 0,177 & 0,152 & 0,305 & 0,069 & 0,142 & 0,222 & 0,109 & 0,091 \\
\hline TETURO & 0,101 & 0,025 & 0,082 & 0,064 & 0,052 & 0,076 & 0,044 & 0,101 & 0,063 \\
\hline TURVIS & 0,094 & 0,05 & 0,144 & 0,121 & 0,067 & 0,092 & 0,095 & 0,172 & 0,104 \\
\hline
\end{tabular}


332

333

334 335

Table 5. Overlapping values for a $30 \mathrm{~m}$ buffer (\%). Lower percentages indicate higher difference between the distributions. Table cells in darker colours indicate greater differences between the habitat used by the bird species and that of the whole study area.

\begin{tabular}{|l|r|r|r|r|r|r|r|r|r|}
\hline Bird (30 $\mathrm{m})$ & AGB & BALM & Deciduous $\%$ & F_veg & GC & \multicolumn{1}{l}{ Hdom } & LSKEW & Pine $\%$ & Spruce $\%$ \\
\hline ACCGEN & 79.77 & 83.51 & 88.10 & 84.70 & 88.07 & 82.16 & 91.68 & 91.77 & 89.96 \\
\hline ACCNIS & 78.76 & 78.93 & 85.56 & 78.59 & 90.84 & 85.56 & 90.15 & 87.89 & 88.80 \\
\hline AEGCAU & 80.84 & 81.59 & 77.35 & 79.38 & 91.16 & 92.94 & 86.71 & 91.64 & 87.47 \\
\hline AEGFUN & 85.86 & 87.62 & 89.64 & 78.93 & 83.27 & 89.53 & 81.02 & 93.21 & 90.59 \\
\hline ASIOTU & 74.45 & 78.28 & 80.76 & 75.24 & 84.10 & 87.65 & 79.44 & 84.84 & 79.04 \\
\hline BONBON & 93.18 & 90.45 & 94.36 & 92.34 & 91.20 & 93.87 & 94.14 & 94.81 & 95.05 \\
\hline BUBBUB & 81.40 & 73.76 & 84.20 & 75.36 & 83.89 & 81.30 & 86.39 & 85.42 & 85.75 \\
\hline BUTBUT & 82.26 & 81.17 & 83.64 & 78.12 & 93.31 & 86.97 & 90.39 & 84.59 & 92.04 \\
\hline CAPEUR & 81.12 & 85.70 & 80.21 & 78.63 & 89.20 & 84.48 & 74.97 & 76.40 & 83.07 \\
\hline DENMIN & 84.93 & 86.74 & 64.34 & 85.27 & 88.11 & 92.72 & 89.61 & 91.34 & 77.64 \\
\hline DRYMAR & 85.05 & 85.88 & 82.79 & 82.20 & 92.08 & 93.60 & 86.02 & 91.93 & 91.12 \\
\hline FICPAR & 74.71 & 79.75 & 82.39 & 86.70 & 94.57 & 72.60 & 83.81 & 78.90 & 86.62 \\
\hline GLAPAS & 90.25 & 91.33 & 78.84 & 84.81 & 88.39 & 89.42 & 91.09 & 94.26 & 90.79 \\
\hline HIPICT & 84.11 & 84.25 & 73.73 & 80.07 & 82.96 & 95.85 & 92.06 & 88.74 & 77.32 \\
\hline JYNTOR & 75.05 & 76.59 & 81.04 & 73.74 & 86.79 & 88.47 & 87.23 & 88.04 & 87.68 \\
\hline LUSLUS & 64.34 & 68.08 & 77.30 & 66.16 & 73.17 & 77.50 & 77.95 & 80.20 & 65.58 \\
\hline PERAPI & 69.96 & 76.28 & 82.51 & 66.99 & 84.29 & 82.91 & 75.59 & 83.75 & 86.55 \\
\hline PHYDES & 90.43 & 86.48 & 82.80 & 91.61 & 90.21 & 78.78 & 88.96 & 86.16 & 89.90 \\
\hline PICCAN & 87.20 & 86.71 & 82.74 & 86.66 & 87.68 & 91.87 & 88.77 & 94.92 & 93.70 \\
\hline PICTRI & 70.48 & 70.54 & 80.42 & 89.91 & 91.33 & 67.55 & 83.54 & 79.43 & 88.37 \\
\hline STRALU & 85.48 & 85.02 & 79.90 & 81.41 & 87.03 & 94.29 & 87.01 & 92.34 & 90.32 \\
\hline STRURA & 82.25 & 87.77 & 86.34 & 77.06 & 89.60 & 94.28 & 86.73 & 90.04 & 86.99 \\
\hline TETRIX & 74.57 & 81.86 & 85.08 & 69.69 & 91.14 & 86.45 & 77.49 & 87.22 & 90.38 \\
\hline TETURO & 88.60 & 91.79 & 90.82 & 92.09 & 91.40 & 90.54 & 95.49 & 88.95 & 91.67 \\
\hline TURVIS & 84.90 & 88.76 & 86.28 & 88.80 & 90.89 & 87.33 & 85.99 & 82.13 & 90.83 \\
\hline
\end{tabular}




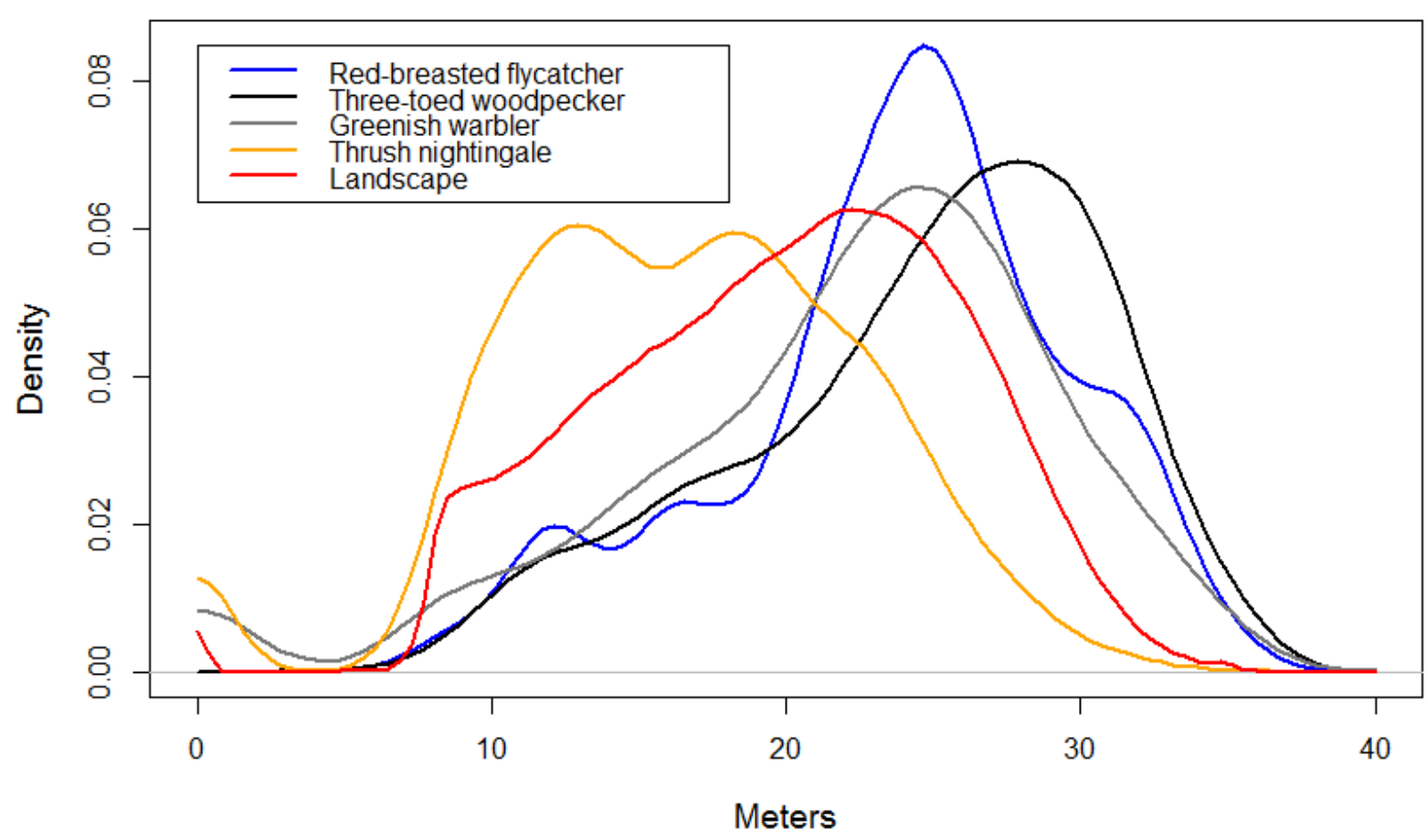

338

339 Figure 5. Density curves for dominant height for the habitat used by four species; three-toed 340 woodpecker, red-breasted flycatcher, thrush nightingale and greenish warbler as well as the landscape 341 (red line). 


\subsection{Success of habitat modelling}

Our results conform to previous knowledge of the bird species' habitat preferences. The habitat characteristics of the buffers around the observation points of specialist species with strict habitat requirements (e.g. three-toed woodpecker; Angelstam \& Mikusiński 1994) differed generally more from the characteristics of the entire study area than those of more generalist species or, putting it in other words, species of which preferred habitat was common in all parts of our study area (e.g. hazel grouse; Åberg et al. 2003). The three-toed woodpecker clearly chose those forest patches within the study area that are characterised by tall trees, high above ground biomass and heterogeneous structures with structurally complex understoreys (BALM). The hazel grouse did not show any clear preference in relation to any of the nine ALS parameters we employed.

However, in the case of some bird species the analysis did not show habitat specialisation although some specialisation was expected based on previous knowledge. We found several reasons for this. First, species that have a large territory and/or home range (> 100 hectares; see Table 1) showed the least difference between the forest characteristics generally available in the landscape and the habitat they used. In a forest landscape consisting of relatively small habitat parcels, the individuals with a large home range are ultimately observed in many different habitat types. Due to private forest ownership and the dominant even-aged stands forest management practice the forests in our study area have a high level of small-scale heterogeneity. In southern Finland the average size of managed stands is approximately 1.2 hectares (Parviainen \& Västilä 2011). As a rule of thumb the home range size of a species increases with its body size, and carnivores have larger ranges than herbivores (e.g. Reiss 1988). Accordingly, large birds of prey like hawks and owls (e.g. ACCGEN, AEGFUN) are among species that in our results showed least habitat preferences. An analysis on a larger landscape scale (i.e. larger grids and buffers) would probably be better suited to study birds with large home ranges.

Second, some characteristics related to the CS observations themselves are quite likely reflected in the results. Compared with other species in the analysis, the majority of the observations of birds of prey were made from afar. The observations of four owl species - Eurasian eagle-owl, Ural owl, tawny owl, and boreal owl - together with northern goshawk had the highest average distances between the bird and observer $\left(75^{\text {th }}\right.$ observation distance percentile approx. 400-500 metres; see Table 1). Further, a large part of the owl observations were auditive; the birds were often observed hooting in the dark. This makes the bird locations even more inaccurate. The finding supports eliminating such inaccurate observations from the dataset.

All but one large sized species with a large territory were observed at a great distance. In the case of the one exception, western capercaillie, the distance between the bird and observer was normally very short 
( $75^{\text {th }}$ percentile 35 metres). As a result, there should not be any location error arising from a long observation distance, yet our data indicate almost no difference between the characteristics of the available habitat and those of the sites where capercaillies were observed. In contrast with our results that showed no preference for tall trees of high biomass, for example, the western capercaillie has even been considered as a species preferring continuous old-growth forest or even an old-growth forest specialist (Helle 1985; Saniga 2003; Virkkala \& Rajasärkkä 2006: Gregersen \& Gregersen 2008). This can be due to a number of reasons. According to Sirkiä et al. (2011) the capercaillie prefers fine-grained mosaic and heterogeneity of forest in its spring time lekking areas. Fragmentation of very dense forests may produce more space for capercaillie males in their lekking sites. Moreover, capercaillies may, for example, prefer younger stands and moist edge habitats with bilberry during the breeding and fledgling (post-breeding) period (see Miettinen et al. 2008) than at other parts of their annual cycle. The result may also be an artefact created by the situation in which both birdwatchers and capercaillies prefer forest roads: birdwatchers for the ease of movement and capercaillies for collecting small pebbles for their gizzard.

Bird species with a small or medium sized territory, especially those that were most often observed from a short distance, stands out by showing clearest signs of habitat preference in relation to the landscape available. Three bird species, in particular, had high preference for the characteristics of mature or oldgrowth stands (esp. dominant tree height): the three-toed woodpecker, red-breasted flycatcher and greenish warbler. The two latter ones are small passerine birds with a small territory. Normally they are observed singing close by and at the core of their breeding habitat $\left(75^{\text {th }}\right.$ observation distance percentile 50 and 40 metres, respectively). The three-toed woodpecker, in contrast, is a medium sized bird with a medium sized territory. However, it is also normally observed close by $\left(75^{\text {th }}\right.$ observation distance percentile 28 metres) which makes the observations very accurate. These characteristics together with the fact that these species are known as habitat specialists of mature and old-growth coniferous forests (Tiainen 1980; Virkkala et al. 1994; Roberge et al. 2008; Pakkala et al. 2014), makes the identification of their habitats by means of ALS derived parameters successful.

Other species which results seem to conform to previous knowledge of their ecology include species preferring deciduous stands and edge habitats. Alike three-toed woodpecker, the lesser spotted woodpecker has a medium sized territory and is normally observed at short range. Out of all species in the analysis, the lesser spotted woodpecker showed the greatest preference for deciduous stands, which is well in accordance with previous studies (Roberge \& Angelstam 2006; Roberge et al. 2008). Other species preferring deciduous forests included the icterine warbler and thrush nightingale. The latter received surprisingly low values for parameters describing the volume of vegetation ( $A G B$ and $F_{-}$veg, especially). This is likely to be due to the fact that thrush nightingales are normally observed singing close to an edge and therefore the buffer around the observation point is likely to include habitat pixels with zero values (i.e. agricultural lands, urban areas, water and so on). We ran a test of the individual thrush nightingale buffers and found out that nearly half of the pixels had zero values for the number of 
vegetation hits (F_veg), for example. This is in high contrast with the habitat pixels inside red-breasted flycatcher buffers of which only $15 \%$ had zero values. A similar pattern probably holds true for the Eurasian wryneck and long-eared owl both of which are species that also prefer edge habitats (Väisänen et al. 1998).

There were, however, few species for which the results found were in discordance with their known ecology and habitat preferences. These results are likely to be artefacts caused by the combination of the species' ecological traits and observation factors. Our results regarding the honey buzzard, for example, suggest that the species would prefer habitats with low biomass, low lying trees, and sparse vegetation. This is not in accordance with what is known about the breeding habitats of honey buzzard: the species nests in mature mixed stands with Norway spruce, birches and European aspen (Björklund et al. 2015). However, the CS data are mostly of individuals seen hunting or displaying over their territory, and not from their nest site where the species is very hard to observe. Therefore, the results relate more to the characteristic of honey buzzard's hunting grounds than its core territory.

\subsection{Applicability of the methodological setup}

Our results indicate the usefulness of structural ALS based forest parameters for studying bird ecology as previous studies have already revealed (Hill et al. 2004; Bradbury et al. 2005; Clawges et al. 2008; Graf et al. 2009; Goetz et al. 2010). Our set of structural forest parameters revealed habitat preferences in the case of several bird species which implies potential for using them in habitat models. However, CS data should not be used with models/tools that require the assumption of the dataset being independent sample from the unknown probability distribution. Particularly BALM (basal area larger than mean) and Hdom (dominant height) revealed differences among multiple bird species. While Hdom describes the development of the higher canopy, BALM expresses the ingrowth of understorey vegetation under the dominant tree crowns. Previous studies have shown that joint variables explain better patterns related to bird habitat selection (Heikkinen et al. 2004). These particular parameters, Hdom and BALM, were both obtained using a combination of ALS and field plots. An alternative to Hdom derived from ALS data only could be the height of the CHM which, although we employed it in an earlier study (Vihervaara et al. 2015), it was ruled out among the parameters reported in this article because Hdom showed more relevant results. On the other hand, no ecology studies have considered the use of BALM before, and its use has so far been restricted to forest science (Gove 2004). Although many alternatives for estimating BALM from ALS have been proved reliable (Valbuena et al. 2014), current research has not yet found any alternatives to $B A L M$ derived from ALS data only.

Our set of structural forest parameters revealed habitat preferences in the case of several bird species which implies potential for using them in habitat models. However, one essential assumption of modelling species distributions from presence-only records is that the data are an independent sample from the species' unknown probability distribution of occurrence (Gomes et al. 2018). Our CS data do 
not fulfil this requirement, and we believe that in general most CS data of birds do not meet this condition. This may be a serious drawback from the monitoring point of view. It is essential to understand the characteristics and limitations of CS data, and assumptions and pitfalls of the used species distribution modelling method.

The ALS data are already freely available and the data are expected to cover the entire land area of Finland by 2019 (National Land Survey 2016), which creates an opportunity to apply the same methodology elsewhere. Multiple European countries have already reached the 100\% ALS data coverage. Because of the increasing availability of ALS data, we also tested the reliability of indicators derived directly from the ALS data (e.g. Nelson et al. 1984; Lefsky et al. 2002; Miura \& Jones 2010; Valbuena et al. 2017) without the support of field information for modelling and estimating forest parameters (e.g. Næsset 2002; Nelson et al. 2007; Asner \& Mascaro 2014). Among many options that were initially tested (data not shown), we found two variables- Lskew and $F_{-}$veg - that could be employed as proxies of forest parameters and linked to the bird species considered in this study. While F_veg (the proportion of ALS first echoes reflected from vegetation) can be considered as a ALS proxy for canopy cover (Nelson et al. 1984), Lskew (a ratio of L-moments showing the skewness of ALS echo height distribution) tells us about the availability of light passing through the dominant tree crowns (Valbuena et al. 2017). The reason for obtaining relevant results from these in particular is an indication that these characteristics can be among the most relevant in defining bird habitat preferences. In contrast with the remaining forest parameters requiring the acquisition of field plots, variables obtained directly from the ALS data could substantially increase the potential uses of these data. It can, as well as to decrease costs, enable us to measure the environment directly from ALS for the purpose of habitat characterization (Vierling et al. 2008) - in some cases as accurately as when including field data in the analysis. Further research should be devoted to investigating whether the inclusion of field data from forest plots could be critical to the habitat characterization of any particular species.

One important question to consider is the size of the buffer around each observation point. The buffer has to be large enough to deal with the inaccuracies of the CS observation data. The accuracy by which bird enthusiasts mark a spot on a digital map when reporting a bird observation is rarely very high. Choosing one or only a few pixels as the bird's habitat (location) would quite likely also exceed the accuracy of the ALS data. On the other hand, increasing the buffer radius around each observation point beyond 50 metres ( 0.8 hectares in area) leads to a decrease in the difference between the buffers and the whole landscape. Mainly due to private ownership, which in Finland typically implies small forest stands (Parviainen \& Västilä 2011) and large structural heterogeneity (Valbuena et al. 2016), buffers larger than one hectare begin to include parts of other habitat patches than of that where the bird was actually observed. Determining the suitable buffer size would require further investigation.

It is important to keep in mind that the CS data that we used do not represent a probability sample and therefore it should be carefully considered whether statistical testing should be applied for the data, and 
whether statistical significance tests would be valid for these purposes. The approach of combining CS and ALS (with or without field plots) should always be considered species-specifically in relation to species ecology and the quality of observations (Pettorelli et al. 2014; Vihervaara et al. 2015).

502 Nevertheless, we consider that combinatory studies with CS and ALS data holds considerable potential 503 to be used in revealing the suitable habitats of many specialised species across the landscape. Because 504 of this, similar analyses would also be applicable to detecting areas of special conservation value (Farrell et al. 2013; Rechsteiner et al. 2017), and in biodiversity conservation in general (Butchart et al. 2010). Further, proxy maps for biodiversity in landscape-scale ecosystem service assessments (Nelson et al. 2009; Kopperoinen et al. 2014) can be created by similar means. Furthermore, the tested forest parameters have many potential applications in ecosystem service analyses (Pettorelli et al. 2014). Our study will be taken further by running the species distribution maps based on the results of this study.

Citizen science, with careful data refinement and consideration of the limits of CS observations, showed much potential for being used in further analyses in predicting the potential habitats of some forest bird species. These were species that were typically observed close-by and at the core of their territories.

514 Using these types CS observations for predicting the habitats of species with large home ranges, for example, would require a somewhat different approach (larger buffers, more careful consideration of the observation times and other circumstances etc.). Means of coping with the uneven distribution observation effort could also be developed. A compensation factor for roads and nearness of towns and cities could be devised, for example. The quality of CS observations could also be raised by some quite easy means. Location errors in observations could be overcome by in-situ reporting with smart phone applications using GPS (already partly in place) and birdwatchers could be directed to report more useful data by redesigning reporting forms (now, in Tiira, only giving the location of the observer in mandatory, for example).

\section{CONCLUSIONS}

This study showed the potential of combining CS bird observation data with forest parameters derived from ALS with field measurements or ALS alone in detecting the habitats preferred by several forest dwelling bird species. In general, bird species with small or medium territories reflected better their true habitat preferences than species with large territories. Also the way how CS observations are made and recorded plays a role - if the observation is made from a close distance and if the species is rather seen than only heard the coordinates can be expected to be more accurate. We therefore conclude that the precision of species location in data collected via CS must be in accordance with the spatial resolution of the RS data for this type of analysis to be useful. We emphasize that expertize of species ecology is essential as well as a thorough understanding of the CS data including factors related to reporting observations. On the whole, the use of CS with ALS holds great promise for modelling bird habitats for 
specialised species and can be expected to contribute to ecosystem mapping and assessment also on a larger scale.

\section{ACKNOWLEDGEMENTS}

Local BirdLife partners Tavastia Proper Ornithological Society/Juhani Kairamo and Pirkanmaa Ornithological Society/Jukka T. Helin. The CLIMES project (Academy of Finland), FRESHABIT-LIFE IP 467 project, MAES Finland project, The IBC-CARBON project funded by The Strategic Research Council (SRC) at the Academy of Finland (Grant n:o 312559). We thank anonymous reviewers for very productive feedback in preparation of the manuscript.

\section{REFERENCES}

Åberg, J., Swenson, J.E. \& Angelstam, P. (2003) The habitat requirements of hazel grouse (Bonasa bonasia) in managed boreal forest and applicability of forest stand descriptions as a tool to identify suitable patches. Forest Ecology and Management, 175, 437-444.

Angelstam, P. \& Mikusiński, G. (1994) Woodpecker assemblages in natural and managed boreal and hemiboreal forest - a review. Annales Zoologi Fennci, 31, 157-172.

Asner, G.P. \& Mascaro, J. (2014) Mapping tropical forest carbon: Calibrating plot estimates to a simple LiDAR metric. Remote Sensing of Environment, 140, 614-624.

Axelsson P. (2000) DEM generation from laser scanner data using adaptive TIN models. International Archives of Photogrammetry and Remote Sensing, 33 (Part B4), 110-117.

Barbet-Massin, M., Thuiller, W., \& Jiguet, F. (2012) The fate of European breeding birds under climate, land-use and dispersal scenarios. Global Change Biology, 18(3), 881-890.

Bird, T.J., Bates, A.E., Lefcheck, J.S., Hill, N.A., Thomson, R.J., Edgar, G.J., Stuart-Smith, R.D., Wotherspoon, S., Krkosek, M., Stuart-Smith, J.F. \& Pecl, G.T. (2014) Statistical solutions for error and bias in global citizen science datasets. Biological Conservation, 173, 144-154.

Björklund H., Valkama J., Tomppo E. \& Laaksonen T. (2015) Habitat effects on the breeding performance of three forest-dwelling hawks. Plos One, 10(9), e0137877.

Bradbury, R.B., Hill, R.A., Mason, D.C., Hinsley, S.A., Wilson, J.D., Balzter, H., Anderson, G.Q., Whittingham, M.J., Davenport, I.J. \& Bellamy, P.E. (2005) Modelling relationships between birds and vegetation structure using airborne LiDAR data: a review with case studies from agricultural and woodland environments. Ibis, 147(3), 443-452.

Brokaw, N. \& Lent, R. (1999) Vertical structure. In Hunter, M. (Eds.) Maintaining Biodiversity in Forest Ecosystems, pp. 373-399, Cambridge Univ. Press, Cambridge, UK.

Butchart, S.H.M., Walpole, M., Collen, B., van Strien, A., Scharlemann, J.P.W., Almond, R.E.A., Baillie, J.E.M., Bomhard, B., Brown, C., Bruno, J., Carpenter, K.E., Carr, G.M., Chanson, J., Chenery, A.M., Csirke, J., Davidson, N.C., Dentener, F., Foster, M., Galli, A., Galloway, J.N., Genovesi, P., Gregory, R.D., Hockings, M., Kapos, V., Lamarque, J.F., Leverington, F., Loh, J., McGeoch, M.A., McRae, L., Minasyan, A., Morcillo, M.H., Oldfield, T.E.E., Pauly, D., Quader, S., Revenga, C., Sauer, J.R., Skolnik, B., Spear, D., Stanwell-Smith, D., Stuart, S.N., Symes, A., Tierney, M., Tyrrell, T.D., Vié, J.C. \& Watson, R. (2010) Global Biodiversity: Indicators of Recent Declines. Science, 328, 1164-1168. 
Clawges R., Vierling K., Vierling L., Rowell E. (2008). The use of airborne lidar to assess avian species diversity, density, and occurrence in a pine/aspen forest. Remote Sensing of Environment 112(5), 20642073.

Cohen, W.B. \& Goward, S.N. (2004) Landsat's role in ecological applications of remote sensing. Bioscience, 54(6), 535-545.

Conrad, C.C. \& Hilchey, K.G. (2011) A review of citizen science and community-based environmental monitoring: issues and opportunities. Environmental monitoring and assessment, 176(1-4), 273-291.

Davies, A.B. \& Asner, G.P. (2014) Advances in animal ecology from 3D-LiDAR ecosystem mapping. Trends in ecology \& evolution, 29(12), 681-691.

Dickinson, J.L., Shirk, J., Bonter, D., Bonney, R., Crain, R.L., Martin, J., Phillips, T. \& Purcell, K. (2012) The current state of citizen science as a tool for ecological research and public engagement. Frontiers in Ecology and the Environment, 10(6), 291-297.

Dickinson, J.L., Zuckerberg, B. \& Bonter, D.N. (2010) Citizen science as an ecological research tool: challenges and benefits. Annual review of ecology, evolution and systematics, 41, 149-72.

Farrell, S.L., Collier, B.A., Skow, K.L., Long, A.M., Campomizzi, A.J., Morrison, M.L., Hays, K.B. \& Wilkins, R.N. (2013) Using LiDAR-derived vegetation metrics for high-resolution, species distribution models for conservation planning. Ecosphere, 4(3), 1-18.

Frishkoff, L.O., Karp, D.S., M'Gonigle, L.K., Mendenhall, C.D., Zook, J., Kremen, C., Hadly, E.A. \& Daily, G.C. (2014) Loss of avian phylogenetic diversity in neotropical agricultural systems. Science, 345(6202), 1343-1346.

GEO BON (2015) Global Biodiversity Change Indicators: Model-based integration of remote-sensing \& in situ observations that enables dynamic updates and transparency at low cost. V1.1.

Goetz, S., Steinberg, D., Dubayah, R. \& Blair, B. (2007) Laser remote sensing of canopy habitat heterogeneity as a predictor of bird species richness in an eastern temperate forest, USA. Remote Sensing of Environment, 108(3), 254-263.

Goetz, S.J., Steinberg, D., Betts, M.G., Holmes, R.T., Doran, P.J., Dubayah, R. \& Hofton, M. (2010) Lidar remote sensing variables predict breeding habitat of a Neotropical migrant bird. Ecology, 91(6), 1569-1576.

Gomes, V.H., IJff, S.D., Raes, N., Amaral, I.L., Salomão, R.P., Coelho, L.S., Matos, F.D.A., Castilho, C.V., Lima Filho, D.A., López, D.C. \& Guevara, J.E. (2018). Species distribution modelling: contrasting presence-only models with plot abundance data. Scientific reports, 8(1), 1003.

Gove J.H. (2004) Structural stocking guides: a new look at an old friend. Canadian Journal of Forest Research, 34, 1044-1056.

Graf, R.F., Mathys, L., \& Bollmann, K. (2009) Habitat assessment for forest dwelling species using LiDAR remote sensing: Capercaillie in the Alps. Forest Ecology and Management, 257(1), 160-167.

Gregersen, H. \& Gregersen, F. (2008) Old bilberry forest increases likelihood of Capercaillie Tetrao urogallus lek occupancy in Southern Norway. Ornis Norvegica, 31, 105-115.

Gregory, R.D. \& van Strien, A. (2010) Wild bird indicators: using composite population trends of birds as measures of environmental health. Ornithological Science, 9, 3-22.

Hagar, J.C., Eskelson, B.N., Haggerty, P.K., Nelson, S.K. \& Vesely, D.G. (2014) Modeling marbled murrelet (Brachyramphus marmoratus) habitat using LiDAR-derived canopy data. Wildlife Society Bulletin, 38(2), 237-249. 
Haila Y., Nicholls A.O., Hanski I.K. \& Raivio S. (1996) Stochasticity in bird habitat selection: year-to-year changes in territory locations in boreal forest bird assemblage. Oikos, 76, 536-552.

Heikkinen, R.K., Luoto, M., Virkkala, R. \& Rainio, K. (2004) Effects of habitat cover, landscape structure and spatial variables on the abundance of birds in an agricultural-forest mosaic. Journal of Applied Ecology, 41(5), 824-835.

Helle P. (1985) Effects of forest fragmentation on bird densities in northern boreal forests. Ornis Fennica, $62,35-41$.

Hill, R.A. \& Thomson, A.G. (2005) Mapping woodland species composition and structure using airborne spectral and LiDAR data. International Journal of Remote Sensing, 26(17), 3763-3779.

Hinsley, S., Hill, R., Fuller, R., Bellamy, P. \& Rothery, P. (2009) Bird species distributions across woodland canopy structure gradients. Community Ecology, 10(1), 99-110.

Hosking, J. R. (1990) L-moments: analysis and estimation of distributions using linear combinations of order statistics. Journal of the Royal Statistical Society. Series B (Methodological), 105-124.

Jonzén, N., Lindén, A., Ergon,T., Knudsen, E., Vik, J.O., Rubolini, D., Piacentini, D., Brinch, C., Spina, F., Karlsson, L., Stervander, M., Andersson, A., Waldenströn, J., Lehikoinen, A., Edvardsen, E., Solvang, R. \& Stenseth, N.C. (2006) Rapid advance of spring arrival dates in long-distance migratory birds. Science 312, 1959-1961.

Kerr, J. T., \& Ostrovsky, M. (2003) From space to species: ecological applications for remote sensing. Trends in ecology \& evolution, 18(6), 299-305.

Kopperoinen, L., Itkonen, P. \& Niemelä, J. (2014) Using expert knowledge in combining green infrastructure and ecosystem services in land use planning: an insight into a new place-based methodology. Landscape Ecology, 29, 1361-1375.

Laaksonen, T. \& Lehikoinen, A. (2013) Population trends of boreal birds: continuing declines in longdistance migrants, agricultural and northern species. Biological Conservation 168, 99-107.

Laasasenaho, J. (1982) Taper curve and volume functions for pine, spruce and birch. Communicationes Instituti Forestalis Fenniae, 108, 1-74.

Lefsky, M.A., Cohen, W.B., Parker, G.G. \& Harding, D.J. (2002) Lidar Remote Sensing for Ecosystem Studies Lidar, an emerging remote sensing technology that directly measures the three-dimensional distribution of plant canopies, can accurately estimate vegetation structural attributes and should be of particular interest to forest, landscape, and global ecologists. BioScience, 52(1), 19-30.

Lehikoinen, A., Jaatinen, K., Vähätalo, A.V., Clausen, P., Crowe, O., Deceuninck, B., Hearn, R., Holt, C.A., Hornman, M., Keller, V., Nilsson, L., Langendoen, T., Tománková, I., Wahl, J. \& Fox, A.D. (2013) Rapid climate driven shift in three wintering waterbird species. Global Change Biology 19, 2071-2081.

MacArthur, R.H. \& MacArthur, J.W. (1961) On bird species diversity. Ecology, 42(3), 594-598.

Maltamo, M., Packalén, P., Yu, X., Eerikäinen, K., Hyyppä, J., \& Pitkänen, J. (2005). Identifying and quantifying structural characteristics of heterogeneous boreal forests using laser scanner data. Forest ecology and management, 216(1-3), 41-50.

Melin, M., Matala, J. Mehtätalo, L., Tiilikainen, R., Tikkanen, O.-P., Maltamo, M., Pusenius, J. \& Packalen, P. (2014) Moose (Alces alces) reacts to high summer temperatures by utilising thermal shelters in boreal forests - an analysis based on airborne laser scanning of the canopy structure at moose locations. Global Change Biology, 20(4), 1115-1125. 
Melin, M., Mehtätalo, L., Miettinen, J., Tossavainen, S. \& Packalen, P. (2016) Forest structure as a determinant of grouse brood occurrence-An analysis linking LiDAR data with presence/absence field data. Forest Ecology and Management, 380, 202-211.

Meredith, M. \& Ridout, M. (2016) Package 'overlap' - Estimates of Coefficient of Overlapping for Animal Activity Patterns. Version 0.2.6.

Miettinen J., Helle P., Nikula A. \& Niemelä P. (2008) Large-scale landscape composition and capercaillie (Tetrao urogallus) density in Finland. Annales Zoologici Fennici, 45, 161-173.

Miura, N., \& Jones, S. D. (2010) Characterizing forest ecological structure using pulse types and heights of airborne laser scanning. Remote Sensing of Environment, 114(5), 1069-1076.

Müller, J., Moning, C., Baessler, C., Heurich, M. \& Brandl, R. (2009). Using airborne laser scanning to model potential abundance and assemblages of forest passerines. Basic and Applied Ecology, 10(7), 671-681.

Næsset, E. (2002) Predicting forest stand characteristics with airborne scanning laser using a practical two-stage procedure and field data. Remote sensing of environment, 80(1), 88-99.

National Land Survey (2016) Laser scanning plan covers year 2019.

http://www.maanmittauslaitos.fi/en/professionals/topographic-data/remote-sensing/laser-scanning/laserscanning-plan-covers-year-2019. Accessed 7.11.2016.

Nelson, R., Krabill, W., \& MacLean, G. (1984) Determining forest canopy characteristics using airborne laser data. Remote Sensing of Environment, 15(3), 201-212.

Nelson, R. F., Hyde, P., Johnson, P., Emessiene, B., Imhoff, M. L., Campbell, R., \& Edwards, W. (2007) Investigating RaDAR-LiDAR synergy in a North Carolina pine forest. Remote Sensing of Environment, 110(1), 98-108.

Nelson, E., Mendoza, G., Regetz, J., Polasky, S., Tallis, H., Cameron, D., Chan, K., Daily, G.C., Goldstein, J., Kareiva, P.M. \& Lonsdorf, E. (2009) Modeling multiple ecosystem services, biodiversity conservation, commodity production, and tradeoffs at landscape scales. Frontiers in Ecology and the Environment, 7(1), 4-11.

Näslund. M. (1937) Skogsförsksanstaltens gallringsförsök i tall-skog Primärearbetning. Meddelanden från Statens Skogsförsöksanstalt, 29, 1-121.

Palminteri, S., Powell, G.V., Asner, G.P., \& Peres, C.A. (2012) LiDAR measurements of canopy structure predict spatial distribution of a tropical mature forest primate. Remote Sensing of Environment, 127, 98105.

Pakkala T., Lindén A., Tiainen J., Tomppo E. \& Kouki J. (2014) Indicators of forest biodiversity: which bird species predict high breeding bird assemblage diversity in boreal forests at multiple spatial scales? Annales Zoologici Fennici, 51, 457-476.

Parvinen, J. \& Västilä, S. (2011) State of Finland's Forests 2011. Based on the Criteria and Indicators of Sustainable Management. Ministry of Agriculture and Forestry 5a/2011. 98 pp.

Pettorelli, N., Laurance, W.F., O'Brien, T.G., Wegmann, M., Nagendra, H. \& Turner, W. (2014) Satellite remote sensing for applied ecologists: opportunities and challenges. Journal of Applied Ecology, 51(4), 839-848.

Pearce, J.L. \& Boyce, M.S. (2006) Modelling distribution and abundance with presence-only data. Journal of Applied Ecology, 43, 405-412.

R Core Team (2016) R: A language and environment for statistical computing. R Foundation for Statistical Computing, Vienna, Austria. https://www.R-project.org/. 
Rechsteiner, C., Zellweger, F., Gerber, A., Breiner, F.T. \& Bollmann, K. (2017) Remotely sensed forest habitat structures improve regional species conservation. Remote Sensing in Ecology and Conservation, 3(4), 247-258.

Reiss, M. (1988) Scaling of home range size: Body size, metabolic needs and ecology. Trends in Ecology and Evolution. 3, 85-86.

Repola, J., Ojansuu, R., \& Kukkola, M. (2007) Biomass functions for Scots pine, Norway spruce and birch in Finland. Working Papers of the Finnish Forest Research Institute, 53. Finnish Forest Research Institute.

Roberge J.-M. \& Angelstam P. (2006) Indicator species among resident forest birds - A cross-regional evaluation in northern Europe. Biological Conservation, 130, 134-147.

Roberge J.-M., Angelstam P. \& Villard M.-A. (2008) Specialised woodpeckers and naturalness in hemiboreal forests - Deriving quantitative targets for conservation planning. Biological Conservation, 141, 997-1012.

Rose, R.A., Byler, D., Eastman, J.R., Fleishman, E., Geller, G., Goetz, S., Guild, L., Hamilton, H., Hansen, M., Headley, R. \& Hewson, J. (2015) Ten ways remote sensing can contribute to conservation. Conservation Biology, 29(2), 350-359.

Royle, J.A., Kéry, M., Gautier, R. \& Schmid, H. (2007) Hierarchical spatial models of abundance and occurrence from imperfect survey data. Ecological Monographs, 77(3), 465-481.

Saino, N., Rubolini, D., Von Hardenberg, J., Ambrosini, R., Provenzale, A., Romano, M., \& Spina, F. (2010) Spring migration decisions in relation to weather are predicted by wing morphology among transMediterranean migratory birds. Functional Ecology, 24(3), 658-669.

Saniga, M. (2003) Ecology of the capercaillie (Tetrao urogallus) and forest management in relation to its protection in the West Carpathians. Journal of Forest Science, 49, 229-239.

Simonson, W.D., Harriet, D.A. \& Coomes, D.A. (2014) Applications of airborne lidar for the assessment of animal species diversity. Methods in Ecology and Evolution, 5 719-729.

Sirkiä S., Helle P., Lindén H., Nikula A., Norrdahl K., Suorsa P. \& Valkeajärvi P. (2011) Persistence of Capercaillie (Tetrao urogallus) lekking areas depends on forest cover and fine-grain fragmentation of boreal forest landscapes. Ornis Fennica, 88, 14-29.

Sullivan, B.L., Wood, C.L., lliff, M.J., Bonney, R.E., Fink, D. \& Kelling, S. (2009) eBird: a citizen-based bird observation network in the biological sciences. Biological Conservation, 142(10), 2282-2292.

Tiainen J. (1980) Habitat of the Greenish Warbler Phylloscopus trochiloides (In Finnish with an English summary). Lintumies, 15, 50-53.

Väisänen R.A., Lammi E. \& Koskimies P. (1998) Distribution, numbers and population changes of Finnish breeding birds (In Finnish with an English summary). Otava, Helsinki, Finland.

Valbuena R. (2015) Forest structure indicators based on tree size inequality and their relationships to airborne laser scanning. Dissertationes Forestales 205. Finnish Society of Forest Sciences.

Valbuena, R., Packalén, P., Martín-Fernández, S., \& Maltamo, M. (2012) Diversity and equitability ordering profiles applied to study forest structure. Forest Ecology and Management, 276, 185-195.

Valbuena, R., Packalen, P., Mehtätalo, L., García-Abril, A., \& Maltamo, M. (2013) Characterizing forest structural types and shelterwood dynamics from Lorenz-based indicators predicted by airborne laser scanning. Canadian Journal of Forest Research, 43(11), 1063-1074. 
Valbuena R., Vauhkonen J., Packalen P., Pitkänen J. \& Maltamo M. (2014) Comparison of Airborne Laser Scanning Methods for Estimating Forest Structure Indicators Based on Lorenz Curves. ISPRS Journal of Photogrammetry \& Remote Sensing 95, 23-33.

Valbuena R., Eerikäinen K., Packalen P. \& Maltamo M. (2016) Gini Coefficient Predictions from Airborne Lidar Remote Sensing Display the Effect of Management Intensity on Forest Structure. Ecological Indicators, 60, 574-585

Valbuena, R., Maltamo, M., Mehtätalo, L. \& Packalen, P. (2017) Key structural features of Boreal forests may be detected directly using L-moments from airborne lidar data. Remote Sensing of Environment, 194, 437-446.

Vierling, K.T., Vierling, L.A., Gould, W.A., Martinuzzi, S. \& Clawges, R.M. (2008) Lidar: shedding new light on habitat characterization and modeling. Frontiers in Ecology and the Environment, 6(2), 90-98.

Vierling, K.T., Swift, C.E., Hudak, A.T., Vogeler, J.C. \& Vierling, L.A. (2014) How much does the time lag between wildlife field-data collection and LiDAR-data acquisition matter for studies of animal distributions? A case study using bird communities. Remote Sensing Letters, 5(2), 185-193.

Vihervaara, P., Mononen, L., Auvinen, A.P., Virkkala, R., Lü, Y., Pippuri, I., Packalen, P., Valbuena, R. \& Valkama, J. (2015) How to integrate remotely sensed data and biodiversity for ecosystem assessments at landscape scale. Landscape Ecology, 30(3), 501-516.

Virkkala, R. \& Lehikoinen, A. (2014) Patterns of climate-induced density shifts of species: poleward shifs faster in northern boreal birds than in southern birds. Global Change Biology, 20, 2995-3003.

Virkkala R. \& Rajasärkkä A. (2006) Spatial variation of bird species in landscapes dominated by oldgrowth forests in northern boreal Finland. Biodiversity and Conservation, 15, 2143-2162.

Virkkala R., Rajasärkkä A., Väisänen R.A., Vickholm M. \& Virolainen E. (1994) Conservation value of nature-reserves: do hole-nesting birds prefer protected forests in southern Finland. Annales Zoologici Fennici, 31, 173-186.

Weiner, J. \& Solbrig, O.T. (1984) The meaning and measurement of size hierarchies in plant populations. Oecologia, 61(3), 334-336.

Wiens, J.A. (1989a) The ecology of bird communities. Volume 1. Foundations and patterns. Cambridge Univ. Press, Cambridge, UK.

Wiens, J.A. (1989b) The ecology of bird communities. Volume 2. Processes and variations. Cambridge Univ. Press, Cambridge, UK.

Wiens, J.A., Rotenberry, J.T. \& Van Horne, B. (1987) Habitat occupancy patterns of North American shrubsteppe birds: the effects of spatial scale. Oikos, 48, 132-147.

Zellweger, F., Roth, T., Bugmann, H., \& Bollmann, K. (2017) Beta diversity of plants, birds and butterflies is closely associated with climate and habitat structure. Global Ecology and Biogeography, 26(8), 898906.

Appendix I: Distribution curves for 30 m buffers for 25 birds, 9 forest structure parameters. 